Justyna Piech

University of Lodz

Faculty of Economics and Sociology

e-mail:j.schabek@gmail.com

\title{
Aspekty etyczne w procedurze zamówień publicznych
}

\section{On the role of the ethical attitudes of public procurement employees}

The purpose of the article is to present elements of the public procurement system that are most sensitive to immoral behaviors and attitudes. The article focuses on the profile of public procurement employees and system solutions that improve the ethical attitude of employees.

Keywords: ethics, public procurement, ethical behaviours

JEL Classification: H43, K42 


\section{Wprowadzenie}

Dopuszczenie się korupcji jest zachowaniem niemoralnym. Jedną z najważniejszych płaszczyzn jego występowania w życiu publicznym są sytuacje opierające się na wykorzystaniu procedury zamówień publicznych. Wówczas dotyczy ono personelu, który, działając w imieniu zamawiającego (w rozumieniu art. 2 ustawy z dnia 29 stycznia 2004 r. Prawo zamówień publicznych, dalej: ustawa Pzp), bierze udział w procedurach przygotowania i udzielania zamówień publicznych oraz zawierania umów na roboty budowlane, dostawy i usługi. Zamówienia publiczne są bardzo dużym rynkiem, przez który przepływają strumienie publicznych środków finansowych, w tym pochodzenia unijnego. Wartość tego rynku w Polsce w ostatnich latach szacuje się na blisko 120 mld zł. Stanowi to znaczny odsetek polskiego produktu krajowego brutto. W 2016 r. wartość ta była równa około 5,80\% polskiego PKB (Urząd Zamówień Publicznych, 2017). Ten ważny gospodarczo i społecznie sektor ma bezpośredni wpływ na poziom zatrudnienia oraz na kondycję finansową przedsiębiorstw. Chcąc zminimalizować ryzyko związane z występowaniem korupcji w przypadku zamówień publicznych, można wprowadzić bardziej sformalizowane procedury, lecz taki krok może wpłynąć negatywnie na dynamikę procesu ich udzielania. Niezależnie od stopnia sformalizowania procedur, ostateczna decyzja zawsze przecież zależy od człowieka, dlatego tak istotną rolę odgrywają postawy i wartości etyczne pracowników obsługujących zamówienia publiczne.

Artykuł stanowi analizę funkcjonującego w Polsce systemu zamówień publicznych w celu zidentyfikowania tych jego elementów, które są szczególnie wrażliwe na zachowania i postawy niemoralne.

\section{Istota systemu zamówień publicznych}

Podstawowym celem systemu zamówień publicznych w krajach o gospodarce rynkowej jest uniknięcie sytuacji, w których wydatkowanie środków publicznych na roboty budowlane, dostawy i usługi odbywa się w sposób pochopny, nieracjonalny, nieprzemyślany czy wręcz nieuczciwy. Podstawowymi uczestnikami rynku zamówień publicznych są zamawiający, będący z reguły organami administracji publicznej, i wykonawcy, którzy na ogół reprezentują sektor prywatny. Rolą systemu zamówień publicznych jest to, aby zakupy towarów i usług odbywały się w sposób optymalny z ekonomicznego i społecznego punktu widzenia oraz, co jest szczególnie istotne dla wykonawców, aby wybór ofert odbywał się w oparciu o jednoznaczne i merytoryczne kryteria, a nie według uznania przedstawicieli organów administracji publicznej. System zamówień publicznych może ponadto spełniać rolę stymulującą koniunkturę w okresie stagnacji lub kryzysu gospodarczego przez generowanie popytu na produkty i usługi podmiotów prywatnych.

Istotą zamówień publicznych jest zaspokojenie określonych potrzeb społecznych, zaś konstrukcja tego systemu ma na celu umożliwienie racjonalnego gospodarowania publicznymi zasobami finansowymi. To od obywateli pochodzą środki przeznaczone na sfinan- 
sowanie zamówień, to od obywateli w sposób pośredni zależy również, co i w jakiej wysokości zostanie sfinansowane. Państwo jako dysponent pieniężnych środków publicznych zobowiązane jest do racjonalnego nimi gospodarowania. Poza aspektem ekonomicznym, zamówienia publiczne odgrywają także istotną rolę społeczną. Wiąże się ona z wymogiem zatrudnienia osób z grup defaworyzowanych, wymogiem zatrudnienia wykonawców na warunkach umowy o pracę oraz obowiązkową waloryzacją ich wynagrodzeń. Zamawiający, którzy dysponują publicznymi środkami finansowymi, zobowiązani są wydatkować je według jasnych, zrozumiałych i transparentnych zasad.

Aby móc zrealizować wskazane cele, konieczne było stworzenie odpowiednich ram prawnych. Obecnie w Polsce obowiązuje ustawa Pzp, która zawiera m.in. przepisy implementowane z Dyrektywy Parlamentu Europejskiego i Rady 2014/24/UE z dn. 26.02.2014 r. W sprawie zamówień publicznych, uchylającej dyrektywę 2004/18/WE (dalej: dyrektywa klasyczna). Zawarte w dyrektywie regulacje mają sprzyjać przejrzystości procedur, zapewnieniu rzeczywistej konkurencji, poprawie skuteczności wydatkowania publicznych środków dzięki uproszczeniu i uelastycznieniu obowiązujących zasad udzielania zamówień publicznych oraz umożliwieniu lepszego wykorzystania zamówień do wspierania celów społecznych, takich jak ochrona środowiska, przeciwdziałanie wykluczeniu i marginalizacji społecznej czy niepożądanym zmianom w środowisku naturalnym, prowadzącym do zmian klimatycznych.

Jednym z podstawowych warunków poprawnego funkcjonowania systemu zamówień publicznych służących jego przejrzystości jest zasada jawności postępowania. Gwarancją przejrzystości zamówień publicznych są m.in.: publikowanie ogłoszeń o zamówieniach, zapraszanie do udziału w aukcjach elektronicznych, informowanie o wyborze najkorzystniejszej oferty, ofertach odrzuconych, wykonawcach wykluczonych, ogłaszanie o udzieleniu zamówienia oraz o unieważnieniu postępowania.

Wejście Polski do Unii Europejskiej spowodowało, że polscy zamawiający i wykonawcy zaczęli uczestniczyć we wspólnym rynku zamówień publicznych. Zamawiający, wszczynając procedurę o udzielenie zamówienia publicznego, powinien mieć świadomość, że podmiotami zainteresowanymi mogą być wykonawcy z innych państw członkowskich, z kolei wykonawcy mają możliwość składania ofert poza granicami kraju. Otwarciu na konkurencję służy m.in. publikowanie ogłoszeń o zamówieniu w publikatorach krajowych (w Polsce jest to Biuletyn Zamówień Publicznych), jak i publikatorze wspólnotowym, którym jest Dziennik Urzędowy Unii Europejskiej (Sadowy, 2013).

Nowe, elastyczne regulacje dyrektywy klasycznej zmniejszają obciążenia po stronie wykonawców. Obecnie na etapie kwalifikacji do udziału w postępowaniu zamawiający muszą akceptować oświadczenia własne wykonawców, natomiast przedstawienia dokumentów potwierdzających spełnienie warunków udziału w postępowaniu można wymagać jedynie od wykonawcy, którego oferta została wybrana jako najkorzystniejsza pod względem ekonomicznym (Olejarz, 2014, s. 8-10). 


\section{Decyzje, czynności i dokumenty procesu udzielania zamówień publicznych szczególnie wrażliwe na zachowania niemoralne}

W procedurze zamówienia publicznego należy wyróżnić trzy podstawowe etapy:

(1) etap przygotowania postępowania,

(2) etap prowadzenia postępowania,

(3) etap realizacji umowy.

Na każdym z tych etapów może dojść do sytuacji, które będą sprzyjały zachowaniom nieetycznym.

$\mathrm{Na}$ etap przygotowania postępowania składa się wiele decyzji oraz dokumentów, w związku z którymi może dojść do naruszenia podstawowych zasad etycznych. Wśród tych decyzji i dokumentów można wymienić:

(1) Oszacowanie wartości zamówienia publicznego Jakkolwiek ustawa Pzp w art. 32 ust. 2 tego zabrania, to jednak często dochodzi do nieuzasadnionego, jednak świadomego i celowego zaniżania wartości zamówienia publicznego. Zaniżenie owo może skutkować m.in. tym, że dane zamówienie znajdzie się w grupie zamówień „krajowych”, a nie „unijnych”. Jest to istotne o tyle, że procedura udzielania zamówień „krajowych” jest szybsza i mniej wymagająca niż w przypadku zamówień ,unijnych”. Zmniejszenie wartości zamówienia może również doprowadzić do dokonywania zakupów bez zastosowania ustawy Pzp.

(2) Planowanie zamówienia publicznego

Plan zamówień publicznych pełni istotną rolę w procesie ich udzielania. Jest to jeden z ważniejszych dokumentów, od którego zaczyna się procedura. Istotnymi elementami planu zamówień publicznych jest szacunkowa wartość zamówień oraz kwota przeznaczona na sfinansowanie każdego z nich. Wartość szacunkowa zamówienia odzwierciedla rynkową cenę przedmiotu, który jest objęty postępowaniem - stanowi wycenę przedmiotu zamówienia w odniesieniu do aktualnych cen rynkowych. Kwota, jaką zamawiający zamierza przeznaczyć na sfinansowanie zamówienia, co do zasady wynika z planu finansowego (lub innego spełniającego podobne funkcje dokumentu, np. planu inwestycyjnego czy budżetu) zamawiającego i oznacza środki, jakie mają być przeznaczone na pokrycie realnych wydatków z tytułu realizacji zamówienia.

(3) Wybór właściwego trybu udzielenia zamówienia publicznego

Katalog trybów udzielania zamówień publicznych zamieszczony jest w ustawie Pzp. Podstawowymi trybami są przetargi: nieograniczony i ograniczony. Pozostałe formy to: negocjacje z ogłoszeniem, dialog konkurencyjny, negocjacje bez ogłoszenia, zamówienie z wolnej ręki, zapytanie o cenę, partnerstwo innowacyjne oraz licytacja elektroniczna. Zastosowanie innych trybów niż podstawowe możliwe jest po spełnieniu przesłanek przewidzianych w ustawie. Przykładem trybów, w których może dochodzić do zachowań nieetycznych, są: dialog konkurencyjny, negocjacje bez ogłoszenia oraz zamówienie z wolnej ręki. W tych przypadkach dochodzi do bezpośredniego kontaktu z wykonawcą, który może, w zależności od wybranego trybu, wpływać na opis przedmiotu zamówienia 
bądź warunki udziału w postępowaniu. Trybów negocjacyjnych należałoby używać tak, aby nie budziły wątpliwości uczestników postępowania, z zachowaniem zasad przewidzianych w ustawie Pzp. Zaletą tych trybów jest to, że pozwalają one właściwie określić potrzeby zamawiającego i uniknąć sporów przy wykonywaniu kontraktów.

(4) Wadliwe sporządzanie dokumentów przetargowych

Na dokumentację przetargową składają się: specyfikacja istotnych warunków zamówienia (dalej: SIWZ) wraz z załącznikami oraz ogłoszenie o zamówieniu. W treści SIWZ zawarte są warunki udziału w postępowaniu, kryteria oceny ofert oraz niezbędne informacje dotyczące terminu oraz miejsca składania ofert. Bardzo istotnym elementem SIWZ jest opis przedmiotu zamówienia. Dzięki niemu wykonawcy są w stanie zapoznać się z przedmiotem zamówienia i złożyć oferty. Na tym polu może dochodzić do nadużyć. Najjaskrawszym tego przykładem może być używanie przez zamawiających nazw własnych bądź znaków towarowych, co zgodnie z art. 29 ust. 3 ustawy Pzp jest zabronione. Świadome ograniczanie konkurencji poprzez formułowanie warunków udziału w postępowaniu tak, aby odpowiadały określonemu, wybranemu wcześniej podmiotowi, należy uznać również za zachowanie nieetyczne. Stawianie warunków nieproporcjonalnych i nieadekwatnych do przedmiotu zamówienia zawęża krąg potencjalnych wykonawców. Kryteria oceny ofert są tymi elementami dokumentacji przetargowej, które decydują o wyborze najkorzystniejszej oferty. Przy sporządzaniu dokumentacji przetargowej zamawiający ma wiele możliwości naruszenia zasad przewidzianych w ustawie Pzp, jak również podstawowych zasad etycznych.

Kolejnym etapem udzielania zamówień publicznych jest prowadzenie postępowania. W zależności od wyboru trybu, w jakim będzie przeprowadzane postępowanie, czynności te będą się różniły. Poniżej opisane zostały czynności, które wykonywane są w trybie przetargu nieograniczonego. Po przygotowaniu niezbędnej dokumentacji i jej opublikowaniu na etap prowadzenia postępowania składa się:

(1) Udzielenie odpowiedzi na pytania

Odpowiedzi na pytania wykonawców czasami mogą doprowadzić do zmiany opisu przedmiotu zamówienia bądź zmiany innych ważnych elementów dokumentacji przetargowej, np. warunków udziału w postępowaniu. W takiej sytuacji może dochodzić do preferowania pewnych wykonawców. Etap zadawania pytań do dokumentacji przetargowej jest ważny, niemniej jednak należy unikać sytuacji, w których w konsekwencji udzielania odpowiedzi na pytania potencjalnych wykonawców zostanie ograniczony ich krąg. Zamawiający podczas udzielania odpowiedzi musi kierować się obiektywizmem, bezstronnością oraz fachową wiedzą.

(2) Przyjmowanie ofert

Bardzo istotne jest wskazanie daty i godziny składania ofert, po przekroczeniu których staje się to niemożliwe. Przyjmowanie ofert po tak szczegółowo określonym terminie należy uznać za naganne. Zamawiający powinni również pilnować, aby w sytuacji zmiany terminu bądź godziny składania ofert informować o tym wykonawców wystarczająco wcześnie. 
(3) Ocena ofert i wybór najkorzystniejszej oferty

Podczas badania treści złożonych przez wykonawców ofert zamawiający musi dokonać ich starannej oceny. Na tym etapie najważniejsze jest wybranie rzetelnego wykonawcy, który wykona przedmiot zamówienia z należytą starannością. Jest to kluczowy moment w procedurze, który decyduje o tym, kto zdobędzie kontrakt i w jaki sposób będzie on realizowany. Oprócz formalnego badania ofert istotne jest także, czy oferta nie zawiera rażąco niskiej ceny, czy wykonawca nie podlega wykluczeniu, czy spełnia warunki udziału w postępowaniu i szereg innych rzeczy. Każda z tych czynności dokonywana jest przez pracowników reprezentujących zamawiającego, i to na nich spoczywa odpowiedzialność za prawidłową ocenę i wybór wykonawcy. Sama ocena stopnia wypełniania tych kryteriów wymaga nie tylko dużej wiedzy, ale i przestrzegania przez zamawiającego norm etycznych.

Po wyborze najkorzystniejszej oferty, lecz przed podpisaniem umowy, wykonawcom biorącym udział w przetargu przysługują środki ochrony prawnej, w tym możliwość odwołania się od decyzji zamawiającego. Odwołanie jest narzędziem, dzięki któremu wykonawca może skutecznie walczyć o zdobycie kontraktu.

Zakończeniem etapu prowadzenia postępowania jest zawarcie umowy o zamówienie publiczne z wybranym wykonawcą. Po zawarciu umowy do obowiązków zamawiającego należy nadzór nad jej realizacją. Polega on na przestrzeganiu jej zapisów, kontrolowaniu zmian umowy, o ile takie zostały przewidziane w dokumentacji przetargowej, oraz egzekwowaniu kar umownych. Kary umowne odgrywają ważną rolę w umowie o zamówienie publiczne, ponieważ mają one dla wykonawcy charakter prewencyjno-motywujący. Należy jednak pamiętać, że kary powinny być adekwatne do przewinień. Wysokie kary umowne odstraszają wykonawców przed składaniem ofert w postępowaniu, co skutkować może unieważnieniem procedury bądź złożeniem oferty, której wartość kilkakrotnie przekroczy kwotę przeznaczoną na sfinansowanie zamówienia. Nie da się odpowiednio wykonać umowy bez odwołania do fazy przetargowej, ponieważ na tym właśnie etapie kształtuje się przyszła umowa. Wszelkie zmiany dokumentacji przetargowej dokonane pod wypływem pytań formułowanych w trakcie trwania procedury przenoszone są do umowy. Należy podkreślić, że zmiany umowy można dokonać w ściśle określonych przypadkach. Nierzetelny bądź nieuczciwy nadzór nad realizacją zamówienia, który może doprowadzić do strat finansowych, stanowi kolejny przykład nieetycznego zachowania reprezentantów zamawiającego.

\section{Propozycje rozwiązań wspierających postawy etyczne wśród pracowników administracji publicznej}

Wśród propozycji rozwiązań wspierających postawy etyczne pracowników zamówień publicznych znaleźć powinny się regulaminy oraz kodeksy etyczne, w treści których należy zawrzeć uniwersalne zasady (sumienność w wykonywaniu obowiązków, niezależ- 
ność, obiektywizm, rzetelność w ocenie merytorycznej pracy) i wartości etyczne (odpowiedzialność, sprawiedliwość, uczciwość, przejrzystość). Kodeks etyczny powinien składać się z zapisów definiujących grupę docelową (grupę osób, do których jego zapisy są adresowane), wskazania dobrych praktyk i zasad postępowania w przypadku wykrycia nieprawidłowości, określenia zachowania w sytuacji wystąpienia konfliktu interesów, a także podania sankcji stosowanych w przypadku naruszenia jego zapisów. Kodeks pracowników administracji publicznej powinien określać standardy postępowania urzędników na rzecz realizacji interesu publicznego. Kodeks etyczny może przyczynić się do usprawnienia działalności administracji i zwiększenia zaufania przedsiębiorców poprzez wzmocnienie postaw etycznych pracowników. Kodeksy zawierające zbiór zasad etycznych powinny być obecne w każdej profesji, jednak ich rola nie powinna być większa niż przepisów prawa. W sytuacji, gdy oceną naruszenia przez pracownika obowiązujących zasad zajmuje się wyłącznie komisja etyki oceniająca czyn z perspektywy etycznej i pomija się konsekwencje prawne, a karą staje się jedynie ostracyzm towarzyski, może dochodzić do uniknięcia odpowiedniej kary.

Kodeks etyczny może okazać się jednak niewystarczający do zmiany lub ugruntowania zachowań etycznych, dlatego poziom świadomości etycznej w miejscu pracy powinien być systematycznie podnoszony. Jednym ze sposobów uchronienia pracowników przed zachowaniami nieetycznymi jest edukacja etyczna, czyli uwrażliwienie na kwestie etyczne, uświadomienie zagrożeń, pokazanie sposobu rozwiązania problemów oraz wzmocnienie wewnętrznej postawy etycznej (Filek, 2004, s. 31-32). Narzędziem podnoszenia poziomu świadomości etycznej są szkolenia etyczne. Idea tych szkoleń wyrasta z przekonania, że większość nieetycznych zachowań pracownika wynika raczej z jego niewiedzy lub ze złożoności problemów i zadań, przed którymi jest stawiany, a nie z przyrodzonej człowiekowi nieetyczności. Zadaniem szkoleń jest więc usunięcie przyczyny, jaką może być brak wiedzy o tym, jak należy w danej sytuacji postąpić (Filek, 2004, s. 47).

Wskazując na rozwiązania systemowe, należy również wspomnieć o whistleblowingu. Termin ten pojawił się w latach siedemdziesiątych XX w. w Stanach Zjednoczonych. Transparency International definiuje whistleblowing jako ujawnienie albo przekazanie informacji o nieprawidłowościach, które dotyczą: korupcji lub innych działań o charakterze przestępczym, niedopełnienia obowiązków, niezgodnych z prawem decyzji, sytuacji zagrożenia zdrowia publicznego i środowiska naturalnego, nadużycia władzy, nieuprawnionego wykorzystywania publicznych środków i majątku, rażącego marnowania zasobów publicznych lub złego zarządzania, konfliktu interesów oraz wszystkich działań mających na celu ukrycie tych patologii (Kobylińska \& Folta, 2015, s. 7).

Sposób informowania o przypadkach nieetycznego zachowania pracowników różni się w zależności od kraju. We Francji urzędnicy mają możliwość zgłaszania aktów korupcji do Centralnej Służby Antykorupcyjnej Ministerstwa Sprawiedliwości. W Stanach Zjednoczonych, gdzie powołano specjalne biuro (Office of Special Counsel), prawna ochrona whistleblowera przyniosła oczekiwane rezultaty, ponieważ osoby zgłaszają zachowania nieetyczne bez obawy o represje ze strony pracodawcy. W Danii nie ma określonej procedury informowania o korupcji, istnieje jednak nadzór nad personelem i raportowanie wykroczeń lub podejrzeń dotyczących korupcji. Urzędnik, który sformułował podejrzenia, nie musi obawiać się zwolnienia z pracy lub innych form represji. Często stosowanym rozwiązaniem jest ponadto wprowadzanie kodeksów etycznych służby publicznej, 
w których określa się podstawowe wartości oraz zasady, jakimi należy kierować się w tej profesji. W Norwegii kodeks etyczny jest częścią ustawy przyjmowanej przez parlament, zaś w Wielkiej Brytanii zapisy kodeksu etycznego włączone są wprost do umów o pracę (Filek, 2004, s. 84-86).

Obecnie w Polsce trwają prace nad ustawą o jawności życia publicznego (cf. Uzasadnienie..., 2018). W projektach ustawy możemy spotkać się z określeniem „sygnalista” (ang. whistleblower) oznaczającym osoby, których współpraca z wymiarem sprawiedliwości polega na zgłoszeniu informacji o możliwości popełnienia przestępstwa przez podmiot, z którym osoby te są związane umową o pracę lub innym stosunkiem umownym, co mogłoby niekorzystnie wpłynąć na ich sytuację życiową, zawodową czy materialną. Dotychczas w Polsce żadna ustawa wprost nie określała zasad i środków ochrony sygnalistów. W uzasadnieniu do projektu tej ustawy określone jest zarówno, kto będzie mógł nadawać status sygnalisty, jak i komu będzie można go nadać. Wskazane są również środki ochrony prawnej sygnalisty (cf. Uzasadnienie..., 2018). Zdaniem projektodawcy jasne sformułowanie tych zasad przyczyni się do zmniejszenia obaw osób, które są świadkami popełniania przestępstw, szczególnie ze strony pracodawcy. Przepisy powinny skutecznie zapobiegać działaniom odwetowym w stosunku do osób, które informują o nieprawidłowościach. Obecnie w polskich warunkach whistleblowing jest obarczony ogromnym ryzykiem osobistym dla sygnalisty, nierzadko brakiem wsparcia otoczenia zawodowego, jak również niebezpieczeństwem szykan ze strony pracodawcy. Ustawa ma pozwolić na skuteczną ochronę osób, które dostrzegają nieprawidłowości i nie obawiają się ich ujawniać. Uregulowanie ochrony prawnej sygnalistów w jednym akcie prawnym może przyczynić się do pogłębienia świadomości społecznej odnośnie do tej kwestii.

Ze względów historycznych w Polsce działalność określona jako whistleblowing może mieć zabarwienie pejoratywne i być kojarzona ze współpracą z służbą bezpieczeństwa czy aparatem partyjnym PRL. Aby uniknąc tego rodzaju prostych i szkodliwych skojarzeń, konieczne jest dokładne rozpoznanie i zdefiniowanie tego zjawiska, wykazanie różnic pomiędzy znanym z historii ,donosicielem” a ,whistleblowerem - demaskatorem w dobrej wierze" (Andrzejewski, 2013, s. 282) .

Whistleblowers należą do ludzi, którzy zarówno w życiu publicznym, jak i prywatnym kierują się zasadami moralnymi. Stanowią swoistą podstawę społeczeństwa obywatelskiego. W czasach globalizacji, a więc braku barier komunikacyjnych w wirtualnych wymiarach przestrzeni społecznej, jeszcze bardziej potrzebna jest realna przestrzeń publiczna kształtująca postawy jednostek i społeczności (Zabłocki, 2012, s. 118). Granica między etycznym informatorem a negatywnym donosicielem jest cienka i rozmywa się w świadomości społeczeństwa. Niski poziom świadomości oraz niewłaściwa interpretacja zachowań sygnalisty mogą spowodować jego izolację i wyeliminowanie z zespołu. Jako przyczyny nieujawniania nieetycznych zachowań przez pracowników wskazać należy: strach przed utratą pracy, brak wiary w skuteczność działania organów ścigania, obawę przed przypisaniem informatorowi opinii donosiciela i w końcu brak odpowiedniej ochrony prawnej.

Pracodawca otrzymujący informację o naruszeniach wykrytych w swojej organizacji zwykle bardziej koncentruje uwagę na tym, kto je zgłosił, niż na sposobie ich wyeliminowania. Posiada on wachlarz środków, dzięki którym może dokonać odwetu na pracowniku. Wśród tych działań wymienić można: brak awansu, pozbawienie dodatku pieniężnego, 
oddelegowanie do innych zajęć, problem z udzieleniem zgody na urlop. Bardzo deprymującym dla pracowników środkiem represji jest przeniesienie na niższe stanowisko przy jednoczesnym obniżeniu pensji (Makowski \& Waszak, 2016, s. 87). Najdotkliwszym dla sygnalisty działaniem będzie zwolnienie z pracy, które może być tłumaczone przez pracodawcę restrukturyzacją skutkującą likwidacją stanowiska pracy czy trudną sytuacją finansową i koniecznością ograniczenia kosztów.

\section{Whistleblowing $\mathbf{w}$ procedurze zamówień publicznych}

Sformalizowana procedura udzielania zamówień publicznych nie chroni przed niepraworządnymi zachowaniami. W procedurze zamówień publicznych członek komisji przetargowej na każdym etapie, mając wiedzę o nieprawidłowościach i decyzjach niezgodnych z prawem, ma możliwość złożenia zdania odrębnego (łac. votum separatum). Zdanie odrębne to opinia odmienna od tej prezentowanej przez większość w komisji. Złożenie votum separatum nie może negatywnie wpłynąć na pracę członka komisji. Swoim oświadczeniem ujawnia on, że w trakcie obrad komisji pojawiła się różnica zdań oraz że miał on inne zdanie co do podjętej decyzji. Przewodniczący komisji przetargowej przed zatwierdzeniem protokołu z prowadzonego postępowania przetargowego powinien poinformować o tym fakcie kierownika zamawiającego. Procedura złożenia zdania odrębnego powinna być opisana w regulaminie prac komisji przetargowej.

\section{Podsumowanie}

Niniejszy artykuł nie wyczerpuje wszystkich zagadnień dotyczących zachowań i postaw etycznych pracowników zamówień publicznych. Opisane zostały w nim obszary w procedurze zamówień publicznych szczególnie wrażliwe na zachowania nieetyczne oraz propozycje rozwiązań, które mogą przyczynić się do podniesienia standardów etycznych wśród pracowników zamawiającego. Postawy etyczne pracowników zamówień publicznych są postrzegane przez społeczeństwo jako ważny element życia. Dzieje się tak między innymi dlatego, że środki finansowe, którymi dysponuje zamawiający, są w istocie środkami wszystkich obywateli. Nie można oczywiście pominąć zasad współżycia społecznego, które wyznaczają minimum powszechnie przyjmowanych norm poprawności i uczciwości w relacjach z innymi osobami. Rzecz jasna etyka zawodowa powinna być obecna w każdym zawodzie, bez względu na charakter wykonywanej pracy. 


\section{Bibliografia}

Andrzejewski, M. (2013). Whistblowing, czyli demaskacja pracownicza w zarządzaniu zasobami ludzkimi. Acta Universitatis Lodziensis. Folia Oeconomica, 288, 275-286.

Dyrektywa Parlamentu Europejskiego i Rady 2014/24/UE z dnia 26 lutego 2014 r. w sprawie zamówień publicznych, uchylająca dyrektywe 2004/18/WE, https://www.uzp.gov.p1/_data/assets/ pdf_file/0023/36617/dyrektywa_2014_24_UE.pdf

Filek, J. (red.) 2004. Etyczne aspekty działalności samorządu terytorialnego. Poradnik dla samorząów. Kraków: Małopolska Szkoła Administracji Publicznej Akademii Ekonomicznej w Krakowie.

Kobylińska, A., \& Folta, M. (2015). Sygnaliści - ludzie którzy nie potrafia milczeć. Doświadczenia osób ujawniających nieprawidłowości w instytucjach i firmach w Polsce. Warszawa: Instytut Spraw Publicznych.

Kowalewski, T. (2005). Kodeks etyczny a ksztattowanie zasad etycznych w administracji. Sulechów: Prace Instytutu Prawa i Administracji PWSZ w Sulechowie.

Makowski, G., \& Waszak, M. (2016). Sygnaliści w Polsce okiem pracodawców i związów zawodowych. Warszawa: Fundacja im. Stefana Batorego.

Olejarz, M. (2014). Zamówienia publiczne w Unii Europejskiej po modernizacji-nowe unijne dyrektywy koordynujące procedury udzielania zamówień publicznych. Warszawa: Urząd Zamówień Publicznych.

Prawo zamówień publicznych, ustawa z dnia 29 stycznia 2004 r., Dz.U. z 2017 r., poz. 1579 ze zm.

Sadowy, J. (red.) (2013). System zamówień publicznych w Polsce. Warszawa: Urząd Zamówień Publicznych.

Stawecki, M. (2010). Granice lojalności w samorządzie terytorialnym. Annales. Etyka w Życiu Gospodarczym, 13(1), 133-138.

Urząd Zamówień Publicznych. (2017). Sprawozdanie Prezesa Urzędu Zamówień Publicznych o funkcjonowaniu systemu zamówień publicznych w 2016 r. https://www.uzp.gov.pl/_data/ assets/pdf_file/0024/35178/Sprawozdanie-UZP-za-2016.pdf

Uzasadnienie do projektu ustawy o jawności życia publicznego. (2017, 23 października) http://legislacja.rcl.gov.pl/docs//2/12304351/12465401/12465402/dokument313365.pdf

Wojciechowski, E. (2009). Refleksje na temat zarzadzenia. Warszawa: Wydawnictwo Difin.

Zabłocki, J. (2012). Przeciwdziałanie patologiom w administracji publicznej na przykładzie zjawiska whistleblowingu. W: M. Sadowski \& P. Szymaniec (red.), Prace z historii i teorii prawa oraz administracji publicznej (s. 109-120). Wrocław: Uniwersytet Wrocławski. 